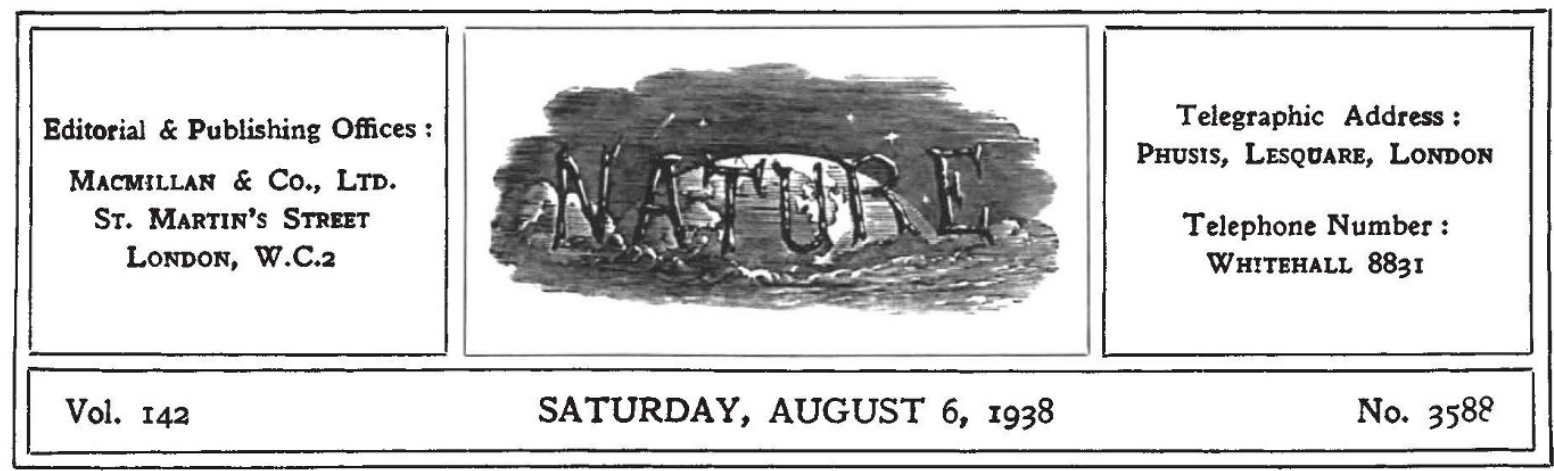

\title{
Science and a World Foundation
}

$\mathrm{O}^{\mathrm{N}}$ several occasions, attention has been directed in NaTURE to the important work undertaken by the Committee on Science and its Social Relations, set up by the International Council of Scientific Unions, and views have been expressed upon the desirability of establishing an organization for the study of the social relations of science (see Supplement to Nature of April 23, 1938). Briefly, the function of the former is to survey the scientific work done in certain fields, with a view to the issue at intervals of a report, with bibliography, concerning the influence of science on human society and the reaction of scientific study to the social environment; while the latter body would seek to advance knowledge on these matters by research and by the discussion and publication of papers, as well as in other ways. It is generally agreed that both bodies should be careful to avoid propaganda and endeavour to be strictly impartial in the exercise of their judgment. Scientific workers are rightly jealous of the high reputation they have earned for their purely objective approach to the questions they study, and it would be lamentable if any ill-considered action resulted in the devaluation of so precious a heritage.

On the other hand, men of science do not spend the whole of their lives in their laboratories. They have at least as great a concern as others in the outcome of their labours, and it should be possible to satisfy these wider interests and aspirations without prejudice to the character or standard of their work. In considering the fit application of the results of their researches, especially in their bearing upon the relations between different countries, a general guiding principle has been enunciated to which the great majority of scientific workers would readily assent: that the welfare of humanity and the interest of the whole community of nations should be placed before the narrower interests of any individual nation. Such a principle could scarcely be held to conflict with that objectivity of outlook which men of science endeavour to maintain. On the contrary, to reach this ideal calls for a mental poise and freedom from bias which anyone might be proud to achieve. It is certainly true to say that, whatever may have been the intentions of individuals, whether as private persons or as the representatives of their countries, its attainment has not proved easy in the past. Frequently, failure has resulted from putting a lower in front of a higher loyalty; the protagonists of different Governments-and it may be doubted if any have been invariably blameless in this respect-when an important crisis has arisen, have adopted too parochial and partisan a conception of their responsibilities.

This fact is brought out convincingly by Senor de Madariaga in "The World's Design", a penetrating analysis of post-War international politics. The author writes with unrivalled authority. For more than six years he was head of the Disarmament Section of the League of Nations Secretariat, and later for about the same length of time he was his country's delegate to the Council, the Assembly, and the Disarmament Conference of the League. The conclusion to which he came as the result of this experience is, therefore, highly significant. He believes that the rivalry between nations will never be resolved until we succeed in convincing those who are in control of affairs that, whether we be Britons or Germans, Frenchmen or Italians, Americans or Japanese, we are all members of one world body; that consequently "there should be no schism in the body ; 
but that the members should have the same care one for another. . . The eye cannot say unto the hand, I have no need of thee. . . . And whether one member suffer, all the members suffer with it; or one member be honoured, all the members rejoice with it". This surely must be the basis of the appeal made even to those who lay particular stress on the virtues of some nations and races at the expense of others; indeed, the necessity to win their approval for that doctrine is the more urgent since our own good is so intimately bound up with theirs. If we ourselves are driven, for the sake of petty retaliation or from a mistaken sense of what constitutes security, to adopt a narrow self-centred course of action, we shall merely prolong and embitter the misunderstanding between nations.

One aspect of an alternative and constructive policy, that relating to trade, is rightly stressed in a report recently prepared by an expert committee of economists, bankers, business men and others for a widely representative Conference on Peace and Economic Policies held at Washington in the spring of this year. As it illustrates the trend of an important section of American opinion, an extract from it is worth quoting. Urging their Government to make every effort to promote a greater interchange of goods and services between the nations generally, they say: "Trade can be called the world's most potent instrument of peaceful change. Abundant trade between nations lessens the economic importance of boundaries; removes most of the causes of complaint about lack of access to raw materials that can justly be made by any State on grounds of peace-time needs; eases tensions over colonies in so far as those tensions are really rooted in economic grievances and are not simple matters of pride and prestige ; lessons the likelihood of exploitation of consumers by foreign or domestic monopolies; makes debt payments easier for debtors and more probable for creditors; facilitates thousands of everyday adjustments that in turn prevent the development of social conflict within nations and between nations." All this is sound sense, but how is the objective to be achieved? Madariaga's proposal is that, instead of working within national environments which are inevitably influenced by national interests and outlooks, we should start from the other end, from the conception of world unity, and work back to differences in national policy, using this central conception to throw new light on the problem in hand.
What part then can men of science play in hastening the desired evolution towards this world outlook in international affairs? In the first place, they can play an extremely important part by contributing to an expert and impartial survey, qualitative as well as quantitative, of the world's resources in land and people, raw materials and manufactured articles, buildings and technical equipment. It is essential that we should begin by ascertaining these fundamental facts, if we are to seek to satisfy the basic needs of all nations and to make adequate provision for a rising standard of life, notably in the more backward countries. Already, much valuable research has been carried out along these lines by responsible bodies, such as the League of Nations, the International Labour Office, the Royal Institute of International Affairs, and the Institute of Pacific Relations. But it is necessary to go further. If such inquiries are to become really effective, they must be co-ordinated, and public attention must be focused upon the conclusions reached.

One example may be given to illustrate their vital importance and their possible repercussions upon events in the international sphere. It is well known to men of science, but not to the general public, that nickel is an essential component of all steels used for armaments as well as for other purposes, and that practically the whole of the world's supply comes from a relatively small area in Canada. Putting these two facts together, can we not draw the inference that it should be possible to limit the manufacture of armaments by controlling the distribution of nickel ? Surely here, actually in the hands of the British Commonwealth of Nations, is a powerful lever which has not been sufficiently explored for regulating international relations and securing peace; and unless world peace is assured, all hope of human progress and prosperity is dimmed. What is true of nickel is true, in greater or less degree, of other important minerals and foods. In fact, the United States and the U.S.S.R. are the only two great powers which do not customarily import large quantities of essential raw materials, and even they lack some commodities indispensable to normal economic life.

It is for reasons such as these that the formation of a Scientific Section of Madariaga's World Foundation (see Nature, June 18, p. 1074) would be welcomed by many leading men of science. A group of this character would be able to guide 
research into problems of world import and be a fitting medium for making the results public. In this way scientific workers would have what they at present lack, opportunity for making the full weight of their collective opinion, based upon an authoritative and impartial study of the facts, felt in the councils of the nations. A lead would thus be given which would no doubt be followed by other groups, drawn together, like men of science, on a functional basis. It has been suggested, for example, that heads of universities and colleges might also combine to form a section of the World
Foundation; and possibly bankers and economists might form another. Such a formation would have the advantage that the members of each section would know and could establish contact with distinguished workers in the same field in other countries. Associated nuclei of thinking men and women would then be found throughout the world, all of whom would be contributing in their several ways to the education of public opinion directed to the same great end-the transformation of a League composed of a few nations into an effective World State.

\section{"La critique est la vie de la science"}

The Grammar of Science

By Karl Pearson. (Everyman's Library, No. 939.) Pp. xxv +359. (London: J. M. Dent and Sons, Ltd., 1937.) 2s. net.

$T$ HE previous editions of the "Grammar of Science" were published in 1892, 1900 and 1911. They have been exhausted for a long time, but, whenever the question of a new issue was mentioned, Karl Pearson used to answer that the old text was out of date and that he was too busy with other work to undertake the necessary revision. It was never undertaken, and the present posthumous edition reproduces the chapters of the original one of 1892, using, however, their text as it was prepared for the edition of 1900 .

We must agree with Karl Pearson that some points in the "Grammar of Science" are out of date now. The progress in all branches of science during the forty-five years since its first appearance has been enormous, and many theories which then appeared as new are now obsolete or nearly 80. Nevertheless, the book is worth preserving. It sets out undying principles, and any book that does that must live. The advance of science beyond where it had got when the book was written will appear far less important a hundred years hence than it does to-day, for the changes of the past forty years will have been changed Looking back now, we see how the state of knowledge-or "belief"-in 1770 is little different from what it became in 1820; though in 1820 the difference seemed very important.

But the "Grammar" does not represent any sort of text-book designed to provide information as to the actual state of science. It is just the grammar of science, or perhaps, of thought, and just here rests its permanent importance. The purpose of the "Grammar" is indicated in the motto which is used as the title of the present article and is explained in the preface, where Pearson says, "There are periods in the growth of science when it is well to turn attention from its imposing superstructure and to carefully examine its foundations. The present book is primarily intended as a criticism of the fundamental concepts of modern science. . . ."

The contents of the book are in harmony with the above announcement. Reviewing the principia, the fundamental conceptions of science which were at the time either generally accepted or being introduced, Karl Pearson analysed carefully their real meaning. He showed the reader how to distinguish between what is known and what is only believed in, what is a dogma and what is a generalized formula invented to put into a systematic order a number of sequences of sense-impressions. Using simple examples, he explained that 'exact sciences' deal only with abstract conceptions which may or may not correspond to realities without losing their importance and usefulness. For example, in physics and chemistry, we speak of electrons as of realities and probably there are realities corresponding to the concept of the electrons; however, even if there were none, nobody would deny the utility and the importance of the concept. But between the world of concepts and the 'real' world of sense-impressions, there is a chasm which can be only bridged by a more or less accurate correspondence. Geometry as a mathematical science deals with conceptions of planes, lines, etc. It is not concerned with dots which we may make on a sheet of paper or with the poles erected by surveyors. Still there is a correspondence-not an 